\title{
FREQUENCIES OF THE COMMON MEFV GENE MUTATIONS IN ADIYAMAN, SOUTHEAST ANATOLIA, TURKEY
}

\author{
Korkmaz DT ${ }^{1, *}$, Atak $\mathrm{PG}^{2}$, Çelik Ç$^{3}$
}

*Corresponding Author: Deniz Taştemir Korkmaz, Ph.D., Vocational School of Health Services, Adıyaman University, TR-02040 Adıyaman, Turkey. Tel: +90-416-223-3800/4154. Fax: +90-416-223-2071. E-mail: deniz-tbio@hotmail.com

\begin{abstract}
Familial Mediterranean fever (FMF) is an autosomal recessive disorder characterized by fever and serosal inflammation. The reasons for the disorder are mutations in the Mediterranean fever $(M E F V)$ gene; the most common of which are M694V, M680I, M694I and V726A. In this study, we aimed to screen these common mutations of the $M E F V$ gene and then determine the prevalence of FMF according to these mutations in Adiyaman, Southeast Anatolia, Turkey. Seven hundred and sixty-seven healthy individuals from the region of Adiyaman participated in the study. Polymerase chain reaction-amplification refractory mutation system (PCR-ARMS) methods were used to determine the common mutations of the $M E F V$ gene. Twenty-six (3.9\%) individuals had only one mutation in the $M E F V$ gene, 25 individuals were heterozygous and one person was homozygous for the V726A mutation $(0.15 \%)$. In the present study, the V726A mutation $(50.0 \%)$ was the most frequent, followed by M694V (38.5\%), M680I (7.7\%) and M694I (3.8\%). It was seen that the carrier rate was very low and the prevalence of FMF was $0.15 \%$, according to the common mutations of the $M E F V$ gene in Adiyaman, Southeast Anatolia, Turkey.
\end{abstract}

\footnotetext{
${ }^{1}$ Vocational School of Health Services, Adıyaman University, Adiyaman, Turkey

${ }^{2}$ Adiyaman Obstetrics and Gynecology \& Child Diseases Hospital, Adiyaman, Turkey

${ }^{3}$ Department of Biology, Faculty of Sciences and Letters, Adiyaman University, Adıyaman, Turkey
}

Keywords: Adıyaman population; Familial Mediterranean fever (FMF); Mediterranean fever (MEFV) gene; Mutations.

\section{INTRODUCTION}

Familial Mediterranean fever (FMF) is an autosomal recessive disorder characterized by recurrent fever attacks, serositis, arthritis and erythema. The severe complication in FMF is amyloidosis affected kidneys that resulted in renal failure. Familial Mediterranean fever is prevalent in Mediterranean Basin, affecting Jews, Armenians, Turks, Arabs and Italians [1-3]. Because of the ethnic diversity in Turkey, the rate of heterozygosity is very high, and the estimated prevalence of FMF and the carrier rate are reported as $1 / 1000$ and $1: 5$, respectively [3].

Familial Mediterranean fever is caused by mutations in the $M E F V$ gene that consists of 10 exons and is located on the short arm of chromosome $16 p 13.3$ [4]. This gene encodes a 781 amino acid protein called pyrin (or marenostrin) that has a major role in the regulation of inflammation and apoptosis via interleukin $1 \beta$ (IL-1 $\beta$ ) processing $[3,5]$.

Up to now, 281 mutations have been identified in the $M E F V$ gene and 81 of these were identified in exon 10 [6]. Among these mutations, M694V, M680I, M694I and V726A were reported to be the most common, accounting for nearly $80.0 \%$ of all abnormal alleles in patients. In the present study, we aimed to determine the frequencies of the common $M E F V$ gene mutations (M694V, M680I, M694I, V726A) in 
healthy individuals in Adiyaman, Southeast Anatolia, Turkey, and the carrier rate and mutation frequency of FMF according to these mutations.

\section{MATERIALS AND METHODS}

Study Population. The study involved 767 healthy individuals who had applied for premarital tests at the Adiyaman Obstetrics and Gynecology \& Child Diseases Hospital, Adiyaman, Turkey. It was granted ethical approval by the local health committee and written consent was obtained from all individuals. Collective data (gender, age, hometown) for each individual were obtained. The study group consisted of 395 females and 372 males, and their ages ranged from 18 to 64 years with a mean age of $26.45 \pm 5.54$ years.

Screening the Common MEFV Gene Mutations. Peripheral blood samples were collected from a total of 767 healthy individuals who had applied for premarital tests at the Adiyaman Obstetrics and Gynecology \& Child Diseases Hospital, Adıyaman, Turkey. Genomic DNA was isolated from $0.2 \mathrm{~mL}$ whole blood using a precipitation method in which saturated saline solution was used [7]. Four common MEFV gene mutations (M694V, M680I, M694I, $\mathrm{V726A}$ ) located in exon 10 were screened with polymerase chain reaction-amplification refractory mutation system (PCR-ARMS) methods. Primers used in M694V, M680I, M694I and V726A mutations were selected from previous studies [8]. Internal control primers (forward: 5'-TGT ATC ATT GTT CTG GGC TCT-3', reverse: 5'-AGG GCT GAA GAT AGG TTG AA-3') were also used in the study.

The PCR mixture $(25 \mu \mathrm{L})$ included $1 \times$ PCR buffer, $1.25 \mathrm{mM} \mathrm{MgCl}, 0.02 \mathrm{mM}$ dNTPs, 5 pmol normal/mutant primers, $2.5 \mathrm{pmol}$ internal control primers, 50 ng DNA, and 2 U Taq Polymerase (Fermantas ${ }^{\circledR}$, Thermo Scientific, Waltham, MA, USA). The PCR conditions for M694V, M680I and V726A identification were as follows: one cycle of initial denaturation at $94{ }^{\circ} \mathrm{C}$ for $9 \mathrm{~min}$., followed by 35 cycles of denaturation at $94{ }^{\circ} \mathrm{C}$ for 10 seconds, annealing at $61{ }^{\circ} \mathrm{C}$ for 10 seconds and elongation at $72{ }^{\circ} \mathrm{C} 30 \mathrm{sec}-$ onds; and for identification for M694I was as follows: once cycle of initial denaturation at $94{ }^{\circ} \mathrm{C}$ for $5 \mathrm{~min}$., followed by 35 cycles of denaturation at $94{ }^{\circ} \mathrm{C}$ for 1 min., annealing at $60{ }^{\circ} \mathrm{C}$ for $1 \mathrm{~min}$. and elongation at $72{ }^{\circ} \mathrm{C}$ for $2 \mathrm{~min}$. The PCR products were electrophoresed in $3.0 \%$ agarose gels in $0.5 \times$ Tris-BorateEDTA (TBE) and visualized with ethidiumbromide. The product sizes were $212 \mathrm{bp}$ for M694V, $220 \mathrm{bp}$ for M680I, 184 bp for M694I, 247 bp for V726A, and $360 \mathrm{bp}$ for internal control (Figure 1).

\section{RESULTS}

Seven hundred and sixty-seven healthy individuals (395 females and 372 males) applied for a

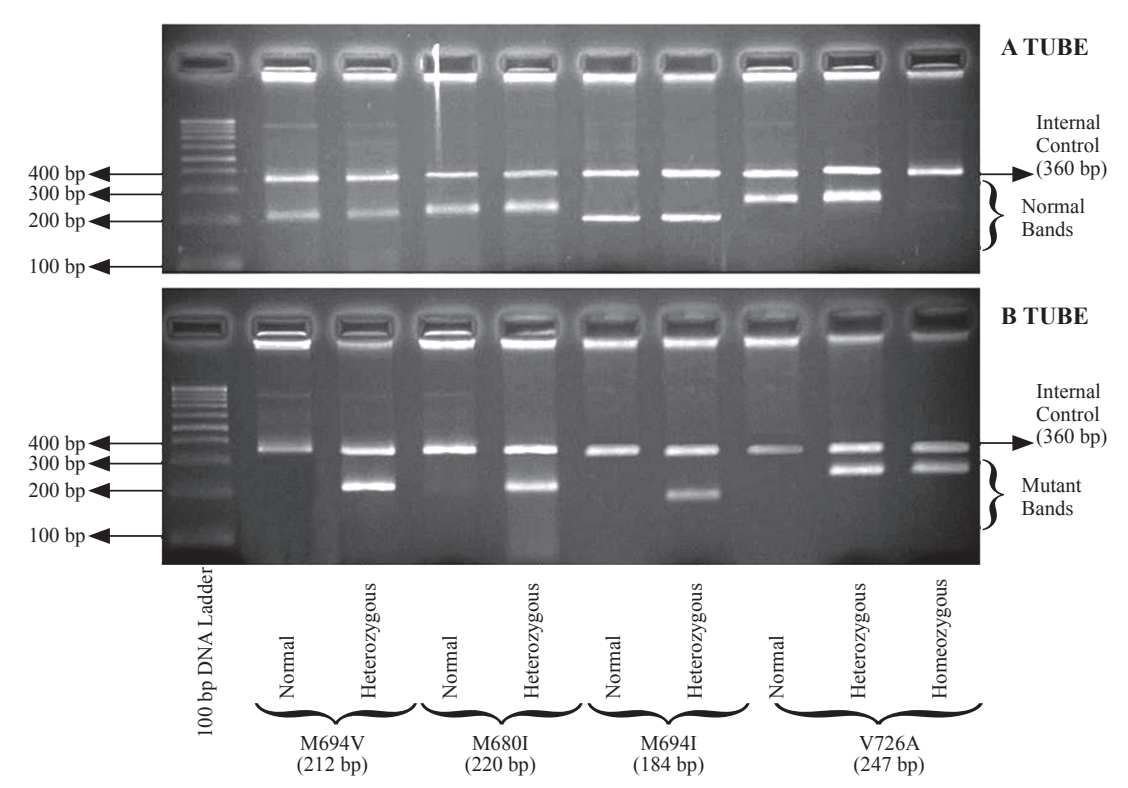

Figure 1. Images of the M694V, M680I, M694I and V726A mutations in 3.0\% agarose gel electrophoresis. 
premarital testing program between November 2011 and December 2012. Among the study population, 667 individuals were from Adiyaman, Turkey, the remaining 100 people were from elsewhere. At the end of the study, we detected mutations in 26 people from the city of Adiyaman, and three people from different areas (Table 1). Because of the aim of the study, we evaluated only the people from Adiyaman, Turkey.

In 641 people $(96.1 \%)$ no common mutation in the $M E F V$ gene was be detected; however, mutations were found in 26 people (3.8\%) from Adiyaman, Turkey. All except one person (3.85\%) carried the V726A mutation in the homozygous state, all mutations $(96.15 \%)$ were heterozygous (Table 1, Figure 1). There was no compound heterozygosity found in the present study. Current results for the 667 healthy people revealed that V726A was the most frequent mutation $(50.0 \%)$ followed by M694V (38.5\%), M680I (7.7\%) and M694I (3.8\%) in Adiyaman, Southeast Anatolia, Turkey (Table 1). The rare mutations detected were M694I and M680I, respectively. Genotyping the four common mutations in the $M E F V$ gene showed that the carrier rate was 3.75\% and the patient rate 1/667 in Adiyaman, Southeast Anatolia, Turkey.

\section{DISCUSSION}

In the present study, we reported the frequencies of the common $M E F V$ gene mutations (M694V, M680I, M694I, V726A) in Adiyaman, Southeast Anatolia, Turkey. In Turkey, the allele frequency is very heterogeneous and according to the literature,
Turks are a very high risk population for FMF $[4,9]$. It is known that the incidence of FMF is $1 / 1000$ and the carrier rate is $15.0-34.0 \%$ reported in various studies in Turkey $[4,10]$. Most of mutations leading to FMF are seen in exon 10 of the $M E F V$ gene. Looking at the distribution by geographic region in Turkey, exon 10 mutations in the $M E F V$ gene are M694V, V726A, M680I in Southeast and Middle Anatolia, Turkey; M694V, M680I, V726A, K695R and $\mathrm{R} 761 \mathrm{H}$ in the Black Sea region, and M694V, M680I, K695R, V726A, M694I, R761H in the Trakya region of Turkey $[9,11,12]$. In general, it was reported that M694V was the most common mutation seen in Turkey [2-4,13]. However, in the present study, the most frequently found mutation was V726A (50.0\%), followed by the M694V (38.5\%), M680I (7.7\%) and M694I (3.8\%) mutations. Sharkia et al. [14] reported that the V726A mutation was the predominant mutation with a $33.0 \%$ frequency in the Muslim Arab population of Israel. The V726A mutation was also reported as the most seen mutation of the MEFV gene in Egypt and Kuwait $[15,16]$. In addition to the Arab population, V726A was the most frequent mutation in the Slovenian population [17].

Our data showed that the carrier rate in the Adiyaman population was $3.75 \%$. When compared with previous studies (the carrier rate 1:5), this carrier rate seems to be very low $[3,10]$. On the other hand, the prevalence of FMF was reported as 0.027$0.25 \%$ in Turkey [18-21]. In Tokat, Northern Turkey, the rate was found $0.82 \%$ [21], whereas in Sivas, a central Anatolian city, it was $0.25 \%$ [19], and in Deni-

Table 1. Genotype and frequency of the common $M E F V$ gene mutations in 767 healthy individuals.

\begin{tabular}{|l|c|c|c|}
\hline & \multicolumn{3}{|c|}{ Number of Individuals, $\boldsymbol{n}$ (\%) } \\
\hline Genotype & Adiyaman & Other Cities & Total \\
\hline M694V/wild type & $10(1.50)$ & $2(2.0)$ & $2(1.56)$ \\
\hline M680I/wild type & $2(0.30)$ & $0(0.0)$ & $1(0.13)$ \\
\hline M694I/wild type & $1(0.15)$ & $0(0.0)$ & $12(0.26)$ \\
\hline V726A/wild type & $12(1.80)$ & $0(0.0)$ & $2(0.26)$ \\
\hline V726A/V726A & $1(0.15)$ & $1(1.0)$ & $738(96.2)$ \\
\hline Number of mutations & 26 & 3 & $767(100.0)$ \\
\hline Wild type/wild type & $641(96.1)$ & $97(97.0)$ & $100(100.0)$ \\
\hline Total & $667(100.0)$ & &
\end{tabular}


zli, Western Turkey, the rate was $0.027 \%$ [20]. The regional data about the $M E F V$ gene mutations and FMF is very important, because we showed that the carrier rate was very low and the prevalence of FMF was $0.15 \%$ according to the common mutations of the $M E F V$ gene in Adryaman, Southeast Anatolia, Turkey. However, different mutation in exon 10 and exon 2 of the $M E F V$ gene can also lead to FMF. Because of these reasons, for giving certain results about FMF patient and carrier rates, different $M E F V$ gene mutations must be screened in clinically diagnosed FMF patients in Adiyaman, Southeast Anatolia, Turkey.

\section{ACKNOWLEDGMENTS}

We would like to thank Mustafa Leblebici and his team and technicians working in the laboratory at the Adryaman Obstetrics \& Gynecology \& Child Diseases Hospital, Adiyaman, Turkey for their help during the study period. We are also grateful to laboratory expert Fatih Aymelek, Adryaman University Scientific and Technological Research and Application Center, Adiyaman, Turkey.

Declaration of Interest. This study was supported by the Adiyaman University Research Grant SHMYOBAP2011/ 0001. The authors report no conflicts of interest. The authors alone are responsible for the content and writing of this article.

\section{REFERENCES}

1. Bathelier C, Lenoir G, Lucotte G. Screening for the M694V mutation of the familial Mediterranean fever (FMF) gene in 604 French patients. Genet Couns. 2010; 21(4): 461-466.

2. Ozdemir O, Sezgin I, Kurtulgan HK, Candan F, Koksal B, Sumer H, et al. Prevalence of known mutations in the MEFV gene in a population screening with high rate of carriers. Mol Biol Rep. 2011; 38(5): 3195-3200.

3. Ozturk C, Halıcioglu O, Coker I, Gulez N, Sutçuoglu S, Karaca N, et al. Association of clinical and genetical features in FMF with focus on MEFV strip assay sensitivity in 452 children from western Anatolia, Turkey. Clin Rheumatol. 2012; 31(3): 493-501.

4. Dundar M, Emirogullari EF, Kiraz A, Taheri S, Baskol M. Common familial Mediterranean fever gene mutations in a Turkish cohort. Mol Biol Rep. 2011; 38(8): 5065-5069.

5. Chae JJ, Aksentijevich I, Kastner DL. Advances in the understanding of familial Mediterranean fever and possibilities for targeted therapy. $\mathrm{Br} \mathrm{J}$ Haematol. 2009; 146(5): 467-478.

6. INFEVERS. The registry of Familial Mediterranean Fever (FMF) and hereditary autoinflammatory disorders mutations (http://fmf.igh. cnrs.fr/ISSAID/infevers).

7. Miller SA, Dykes DD, Polesky HF. A simple salting out procedure for extracting DNA from human nucleated cells. Nucleic Acids Res. 1988; 16(3): 1215.

8. Eisenberg S, Aksentijevich I, Deng Z, Kastner DL, Matzner Y. Diagnosis of familial Mediterranean fever by a molecular genetics method. Ann Intern Med. 1998; 129(7): 539-542.

9. Pasa S, Altintas A, Devecioglu B, Cil T, Danis $\mathrm{R}$, Isi $\mathrm{H}$, et al. Familial Mediterranean fever gene mutations in the southeastern region of Turkey and their phenotypical features. Amyloid. 2008; 15(1): 49-53.

10. Tunca M, Akar S, Onen F, Ozdogan H, Kasapcopur O, Yalcinkaya F, et al., Turkish FMF Study Group; Familial Mediterranean fever (FMF) in Turkey: Results of a nationwide multicenter study. Medicine. 2005; 84(1): 1-11.

11. Yigit S, Bagci H, Ozkaya O, Ozdamar K, Cengiz K, Akpolat T. MEFV mutations in patients with familial Mediterranean fever in the Black Sea region of Turkey. J Rheumatol. 2008; 35(1): 106-113.

12. Gunel-Ozcan A, Sayın DB, Dibek Misırlığlu E, Güliter S, Yakaryilmaz F, Ensari C. The spectrum of FMF mutations and genotypes in the referrals to molecular genetic laboratury at Kirikkale University in Turkey. Mol Biol Rep. 2009; 36(4): 757-760.

13. Akpolat T, Özkaya O, Özen S. Homozygous M694V as a risk factor for amyloidosis in Turkish FMF patients. Gene. 2012; 492(1): 285-289.

14. Sharkia R, Mahajnah M, Zalan A, Athamna M, Azem A, Badarneh K, et al. Comparative screening of FMF mutations in various communities of the Israeli society. Eur J Med Genet. $2013 ; 56(7): 351-355$. 
15. El-Garf A, Salah S, Iskander I, Salah H, Amin SN. MEFV mutations in Egyptian patients suffering from familial Mediterranean fever: Analysis of 12 gene mutations. Rheumatol Int. 2010; 30(10): 1293-1298.

16. Elshafey AE, Kader NA, Barakat N, Azab A, Bastaki L, Al-Awadi S. Clinical and molecular genetic study of familial Mediterranean fever in a mixed Arab population. Intern J Acad Res. 2011; 3(3): 204-208.

17. Debeljak M, Abazi N, Toplak N, Stavric K, Kolnik M, Kuzmanovska D, et al. Prevalence of MEFV gene mutations in apparently healty Slovenian and Macedonian population. Pediat Rheumatol. 2011; 9(Suppl 1): P301.

18. Dinc A, Pay S, Turan M, Simsek I. Prevalence of familial Mediterranean fever in young Turkish men. (abstract) Clin Exp Rheumatol. 2000; 18: 292.
19. Onen F, Sumer H, Turkay S, Akyurek O, Tunca $\mathrm{M}$, Ozdogan $\mathrm{H}$. Increased frequency of familial Mediterranean fever in Central Anatolia, Turkey. Clin Exp Rheumatol. 2004; 22(Suppl 34): 31-33.

20. Çobankara V, Fidan G, Turk T, Zencir M, Çolakoglu M, Ozen S. The prevalence of familial Mediterranean fever in the Turkish province of Denizli: A field study with a zero patient design. Clin Exp Rheumatol. 2004; 22(Suppl 34): 27-30.

21. Kisacik B, Yildirim B, Tasliyurt T, Ozyurt H, Ozyurt B, Yuce S, et al. Increased frequency of familial Mediterranean fever in northern Turkey: A population-based study. Rheumatol Int. 2009; 29(11): 1307-1309. 